THE DICTIONARY OF DISEASED ENGLISH 


\title{
The Dictionary of Diseased English
}

\author{
Kenneth Hudson
}

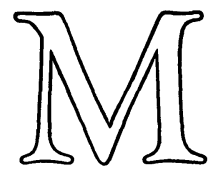


(C) Kenneth Hudson 1977

Softcover reprint of the hardcover 1st edition 1977

All rights reserved. No part of this publication may be reproduced or transmitted, in any form or by any means, without permission.

First published 1977

Reprinted 1978

THE MACMILLAN PRESS LTD

London and Basingstoke

Associated companies in New York Dublin

Melbourne Johannesburg and Madras

ISBN 978-0-333-25853-8 ISBN 978-1-349-04387-3 (eBook)

DOI 10.1007/978-1-349-04387-3

British Library Cataloguing in Publication Data

Hudson, Kenneth

The dictionary of diseased English.

I. English language - Usage - Dictionaries

I. Title

423 PEI625

ISBN 978-0-333-21394-0 


\section{CONTENTS}

Foreword

vii

Context of the Dictionary xi

Introduction xiii

Dictionary I

A Note on Sources $\quad 259$ 


\section{FOREWORD}

The last half-century has seen some powerful, and abundantly justified, criticisms of the increasing corruption of the English language. T. S. Eliot, F. R. Leavis, George Orwell and W. H. Auden come to mind at once. Earlier still, there was Ezra Pound's passionate assertion that when a language goes rotten the very substance of our thoughts and feelings goes rotten too. The same sort of impulse is behind Kenneth Hudson's fascinating and alarming Dictionary of Diseased English.

There seems little doubt that the virtues of decent, clear exposition in speech or writing are less sought at all levels of education today than they were a few decades ago. In such a climate jargon and its more publicly self-conscious relative, gobbledegook, can flourish almost unchecked and almost everywhere. It is virtually impossible nowadays to listen to a discussion among specialists in education without hearing again and again about 'the learning situation' or 'being in the classroom situation'; and no discussion on social work is complete without many references to 'the caring society' or 'the supportive society'. The only consolation is that phrases such as these have their day and thereafter fall out of use. Still, others like them take over.

It is important to distinguish jargon from proper professional and technical language. Specialists do need specialist languages for at least two good reasons: as forms of shorthand to speed up discussions between themselves and as safeguards against their analyses being misinterpreted because some of their words might be read in more than one sense. This is especially necessary in social-scientific studies; their language must be so far as possible cleansed of the ambiguities of subjective readings. It can be a pleasure to eavesdrop on conversations of this kind.

By contrast, jargon and gobbledegook are a special preserve of non-specialists and in particular of non-specialists who would like to be thought intellectually and socially up-to-date. They leap from one fashionable phrase to another, phrases which must, since this is their nature as expendable cult-objects, change from year to year. A quick 


\section{Foreword}

ear for those words and phrases which are on the way out and for those just coming in can be a useful guarantee that we are keeping up with the right social-intellectual group. These can be called 'keeping out' words and phrases; they establish the idea of a sort of club from which most people are excluded. Another group contains language designed to embrace everyone who can be persuaded to read it; this is 'come in' or 'come on' language which has no real subject or substance; or, more exactly, whose substance is its tone itself. This is language which flatters, deceives, disguises, woos. The users of this group are specialists, but their specialism is linguistic persuasion.

I don't want to seem to suggest that all specialists always use their technical language in the pure ways I described earlier. There are some social scientists who use the language of their trade far beyond the needs of the occasion and in conversations with non-specialists. At its best, this is usually because they have fallen poetically in love with the apparatus of the discipline. They are like Scotsmen who walk round Central London in kilts. At its worst, they are often professionally insecure and using the jargon to establish their credentials. As both Kenneth Hudson and I know, since we have both worked in adult education, almost all of us can say almost all we ever have to say about our discipline in words accessible to a reasonably shrewd listener. It is chiefly a matter of being willing to come out from behind the protective wall of our specialist linguistic habits.

It follows that the current kinds of linguistic barbarism are more practised in some disciplines than others. We all know the prosepoem writing on menus, a practice which came over from the United States. My own experience is that in America, no matter what the preposterous claims of the menu, you usually get decent and tasty food at a reasonable price. In England, we have copied the prosepoetry but disregarded the food value. We are given, in most public places, awful food at inflated prices, introduced by entirely spurious claims. Then there are the worlds of advertising and public relations. I treasure a letter from the Customer Service Division Vice President of an American airline, to whom I had complained of careless and offhand treatment which had cost me several hours of exhausting shuttling back and forth. It began: 'Dear Sir, We are privileged to have shared your thoughts on the efficacy of our customer-relations procedures.... Clearly, that kind of letter can be put on the computer for instant use with a facsimile signature. I enjoy remembering also the way a dour-looking Scottish grocer stopped in his tracks a salesman from Glasgow who was giving him fancy patter 
about 'customer promotions' and 'sales enhancing offers' and the like. The grocer said: 'Young man, give me no more of your inducements. Show me your bill of goods and I will tell you whether I will buy.'

Kenneth Hudson is right, too, to accuse the UN and its agencies of particularly awful linguistic practices. There is just one possible partial justification: sometimes they take refuge in gobbledegook so as to keep the boat steady until the danger of a futile political split has receded; plain speech might make such a split unavoidable. For all that, the UN system is a mine of internationally-deodorised, pseudointellectual and pseudo-scientific language. Working in UNESCO, I used to long for a day in which I did not hear about 'a fruitful dialogue' or an 'interface' or 'a viable objective'. And when we hired international non-governmental organisations to carry out parts of the programme we always referred to them in print as 'relevant NGOs' or 'competent NGOs', as though to assure our member states that we wouldn't really ask the International Music Council to carry out a study in world economic trends. It brought back the days when chimney sweeps in Leeds almost always described themselves, on little boards above their front doors, as 'practical sweeps', as though they reckoned we all had fears of sweeps so impractical that they would leave the house even more of a shambles than the 'practical' sweeps certainly did.

In politics, both the far Left and the far Right have their jargons, usually of instant abuse or instant package judgment. Kenneth Hudson, in his preface, quotes Rhodes Boyson on the ways 'the parties of the Left have been practising such (linguistic) destruction for years'. I wish Mr. Hudson had found another spokesman, rather than this pot calling the kettle black. Many of Mr. Boyson's own utterances illustrate how addicted those on the Right can be to this practice.

It is not easily possible and certainly not desirable to read a dictionary such as this from cover to cover. Mr. Hudson's discussion of any particular word is likely to set the reader off adding his own gloss, or recalling words he thinks should have been included. Since the process is a continuous one of invention, overuse and decay, such a book can in one sense never be finished. Perhaps the publishers would have done well to add a dozen blank pages, on to which readers could write their own most flagrant examples. It might all come to have the elements of a semi-intellectual parlour game . . . . if it weren't such a serious matter at bottom. For if we ourselves use language in these ways, and if we let ourselves be steadily battered by them (even 


\section{Foreword}

though it is rather like being battered by pillows stuffed with cotton wool, in the end the process is numbing) if we put up with all this without objecting, we will surely blunt the edge of our own language and so blur our hold on our own intellectual and imaginative lives.

Richard Hoggart 


\section{THE CONTEXT OF THE DICTIONARY}

'If the changes we fear be thus irresistible, what remains but to acquiesce with silence, as in the other insurmountable distresses of humanity? It remains that we retard what we cannot repel, that we palliate what we cannot cure. Life may be lengthened by care, though death cannot be ultimately defeated. Tongues, like governments, have a natural tendency to degeneration: we have long preserved our constitution, let us make some struggle for our language.'

Samuel Johnson: Preface to Dictionary, i75s 


\section{INTRODUCTION}

\section{What is Meant by Diseased English}

Ignorant cooks, with no palate and no interest in food, can spoil the best of raw materials, so that what might in more skilled and more sensitive hands have become a dish to be recalled with pleasure, ends up as nothing better than a repulsive, tasteless mess. So it is with words. No language has better ingredients than English; no language has ever been more monstrously ill-treated and deformed by vandals and incompetents. The most beautiful instrument is always the most vulnerable to abuse and damage.

Linguistic abuse takes many forms. Sometimes it is sheer carelessness and clumsiness:-

'The telephone service in King Island has been characterised by the informality familiar to such services.'

Sometimes it is ignorance or indifference to the proper meaning of a particular word or phrase:-

'The game is riddled with such stories.'

Sometimes it is the kind of nonsense which results from the unthinking and indiscriminate use of a fashionable cliché:-

'The patented pulsing action literally dissolves stress from tired muscles.'

Sometimes it is the cult of the new, the ugly and the shocking for its own sake:-

'A good suit, fashionable and properly accessorised', or

'These can be souvenired overseas at bargain prices.'

Sometimes it is the immigrant's literal, but illiterate, translation from his own language, which strikes roots in the country of his adoption:-

'Pianist George Shearing', or

'He plays piano.' 


\section{Introduction}

Sometimes it is an inability to transfer speech to paper, with no realisation of what punctuation is for:-

'Another thing that attracted me to folk music was discovering

Percy Grainger's arrangements, they are so subtle harmonically.'

Sometimes, and much worse, it is a conscious and cynical combination of iconoclasm and seeking after novelty, a professional job:-

'From the airline that brings you the world. A slice of luxury. This is jetting. This is Qantas. You're the star. Here impeccable service unfolds. Stewards and Hostesses are at your command. An iced drink, a hot towel, at take-off. Then some writing paper. A magazine. Or chess. Maybe a martini. Or whatever you wish. You chat. With your neighbour. Discover he's an Artist. Author. Diplomat. Banker.'*

Most frequently, the torturing and battering of our long-suffering but fortunately still breathing language stems from a longing for grandeur and advertiser's poetry. We therefore have such things as:-

'Fast, strong and perfectly shaped, the gondola embodies all the water-borne magic of Venice. And the agile, singing gondolier has for centuries been a central part of the Venetian legend, transporting sober citizens about their business, or lovers to their secret assignations.' $\dagger$

Or, from the industrialist who, in his efforts to up-grade his simplest statements, has no fear or perception of the ridiculous:-

'We have a very good liaison with the Water Board and we circulate the people concerned.'

Or the unfortunate results of the Mayor's anxiety to make his words match the dignity of his office:-

'Poole is a very democratic place. The dinghy-sailors regularly cohabit with the people on the beach.'

There is nothing new or particularly frightening about the last two examples. They are in the English comic tradition of Sheridan's Mrs. Malaprop and Shakespeare's Dogberry, people who combine a

* Brochure, It's a Woman's World with Quantas, 1975.

$\dagger$ The Reader's Digest Book of World Travel, 1967. 
fondness for fine language with the inability to use and control it. What has grown up in our own time is something much more sinister-a contempt for people who use language accurately and elegantly, and this attitude certainly did not exist in the days of Shakespeare, Sheridan or Dickens. It has now reached such a point of absurdity that, in many circles, the inability to write and talk well is taken as evidence of superior personal worth. Conversely, anyone who has learnt how to discipline his thoughts and his way of expressing them is regarded with the greatest suspicion. If he has a rich vocabulary and can spell and write grammatically, he is obviously a political reactionary and that most dangerous of all contemporary animals, an élitist.

One could, perhaps, tolerate this for a while, irritating and depressing as it may be, in the hope that it could amount to nothing more than the new power-groups flexing their muscles and letting society know that it has a fresh set of masters. Is it, after all, one might ask, so very different from what the Chinese were saying and doing during their Cultural Revolution? If the nation is to be democratised in a thorough-going way, then language cannot expect to escape the same cleansing and levelling process. Workers', soldiers' and peasants' Chinese must, by definition, be different from bourgeois or capitalist Chinese-or Russian, or German, or Portuguese, or any other language one cares to name. One must somehow arrive at a general use of the mother-tongue which will not make simple people feel inferior. National unity demands that the language shall be levelled down.

All one can say about this is that, plausible and commonly heard as the argument is, there is no evidence that either the Russians or the Chinese have ever believed or advocated any such thing. They may have introduced a new, crude and repulsive ideological vocabulary with which to abuse their enemies but, apart from this, their attitude to language appears to have been extremely conservative. Russian and Chinese children today are taught to handle written and spoken Russian and Chinese at least as accurately as their fathers and grandfathers were. Some no doubt succeed better than others, but there is certainly no officially inspired equation between sloppy semiliteracy and a People's Democracy, although the need to condition some responses but not others produces considerable psychological and educational problems. The split or two-level mind is an essential item of self-protection in any country with a totalitarian government. 


\section{Introduction}

In the West, however, things have been rather different, although one hesitates to say better. Our society, it would seem from the people its schools and universities produce, places a low value on literacy, if by literacy one means the ability to use the full resources of the language, to listen and read with comprehension and sensitivity and to speak and write easily and with clarity and grace. An unprejudiced observer might well consider, from the evidence before his eyes and ears, that today's Britain, America or Australia has a vested interest in semi-literacy; we want and we get people who are just literate enough to fill in forms, read street signs and see what is on the label of a medicine bottle, but not sufficiently at home with language to prevent themselves from being drugged and seduced by commercial and political propaganda. Much of this propaganda truly qualifies for the label 'diseased English', in that it is specifically and cunningly designed to work on the half-awake, half-informed mind. It aims neither at comprehension nor at clarity. Automatic responses are its measure of success.

'It has been claimed, [writes Dr. Rhodes Boyson, ${ }^{*}$ ] that the teaching of grammar is a bulwark of civil order. To this I would add that the debasement of the meaning of important words can help to destroy a free society. The parties of the Left have been practising such destruction of words for many years.'

Dr. Boyson, like George Orwell before him, has in mind such emotive, and now largely meaningless phrases as 'social justice', which is now a synonym for 'the creation of envy'-and, as John Stuart Mill said with complete accuracy, envy is 'the most anti-social of all passions'. He was also, no doubt, thinking of words like 'obscene', 'filthy' and 'indecent', which have been taken over by the Left as blunt, heavy weapons with which to attack anything it dislikes, such as private property, private rents and salaries which reward ability and hard work. 'Is this destruction and corruption of words by the Left,' he asks, 'part of the decline of knowledge in an egalitarian age, or is it intentional corruption? Either way it is a bitter commentary on the men who do it. Perhaps we should return to teaching grammar, spelling and meaning in our schools, instead of "social liberation" and "personal orientation" and such rubbish.'

Grammar, spelling and meaning, however, inescapably add up to a subject called English, and, throughout the English-speaking world,

\footnotetext{
* Daily Telegraph, igth December I975.
} 
English appears to be losing its place to something much more modern-sounding and impressive called Communications, the concern of which is not literacy at all. The basic assumption of Communications is that language is just another means of communication, certainly no more important and perhaps even less important than television or films or popular music. This is the message of Marshall McLuhan and his disciples, who insist that print is dead, the days of the book are over, and that the prime duty of the citizen and of those who cater for his needs is to become expert in the mysteries of tape, film and incantation.

The consequence of this continuous barrage of anti-language propaganda is that we have become suspicious of those who speak well. We have come to prefer what has been well-termed 'mutterlanguage'. 'The verbal is out and the visual and the visceral are in. The result is students who take courses in "communications" and tell you that they sort of like, man, you know, dig their teacher.'*

It is possible that we are approaching a point at which the ability to use English with precision and sensitivity has become either the privilege or the burden of very few people. The rest of their fellowcitizens, in that case, will eventually be divided into three groups:-

I. Those who write nonsense without realising it.

2. Those who write nonsense in complete and cynical awareness of what they are doing.

3. The passive victims of (I) and (2).

This disastrous situation is not, however, inevitable and the present Dictionary reflects a belief that the worst can be prevented from happening, but that an essential part of any battle is the ability to recognise one's enemies and to identify their weapons.

The enemies of a free and democratic society are the people who are permitted and encouraged to write things like

'After a period of induction training concentrated on user and large account selling, you will assume complete responsibility for the export sales management control function which you will set up against marketing guide-lines and report directly to the managing director. You will recognise the company commitment to a philosophy of profitable sales attainment consistent with company marketing policy and production capacity.' 


\section{Introduction}

and

'I don't think people are worried about employment. It's more a case of being concerned about the future.'

and

'It is untrue to state that two resolutions passed by the last session of UNESCO's General Conference deprive Israel of the benefits of belonging to that body. The Conference voted to apply sanctions to Israel and to withhold assistance in the fields of education, science and culture.'

The enemies of English use a small but superficially impressive vocabulary. They are fond of knocking the other side off balance with what is, to the ignorant and impressionable, indistinguishable from science. An American Christmas card, produced by one of the wittier members of the academic world, takes the form of three concentric and revolving discs and caricatures the pseudo-scientific style and approach in a masterly fashion. 'This structurally divergent communication,' the message around the extreme edge reads, 'conceptualises a wish that Christmas may bring a meaningful reinforcement of your specific predetermined behavioural patterns.' Each disc carries 24 words of this kind and by rotating the discs one can build up a large number of magnificent but totally meaningless phrases, of the kind that stops communication in its tracks. One can have, for instance, 'child-centred procedural dysfunction', or 'innovatory motivational maladjustment', or 'basic theoretical strategy'. The full range of socio-psychological rubbish is here, ready to dope and bemuse the unwary, and to entertain the privileged and dangerous few who have seen through it all. For those who would find it convenient to have this select vocabulary for reference, the words are:-

Outer disc Activities; communication; resources; synthesis; validation; techniques; consensus; maladjustment; sector; criteria; autonomy; analysis; polarisation; objectivity; strategy; situation; overinvolvement; evaluation; components; dysfunction; methodology; quotients; reorganisation; rationalisation.

Middle disc Consultative; empirical; unstructured; implicit; perceptual; psycho-linguistic; co-educational; reactionary; motivational; academic; conceptual; experimental; socio-economic; hypothetical; ideological; theoretical; developmental; compensatory; diagnostic; xviii 
meaningful; procedural; significant; democratic; sociometric.

Inner disc Disadvantaged; on-going; informal; ultra; interdisciplinary; cognitive; relevant; correlated; extra; innovatory; viable; supportive; élitist; micro; creative; advanced; basic; divergent; programmed; operational; affective; child-centred; multi; emotive.

One could go a long way nowadays with this basic vocabulary, plus a few pronouns and simple verbs.

This is perhaps the point at which one should attempt a definition of diseased English. It is 'English which, either deliberately or unconsciously, is used with so serious a lack of precision that it ceases to be an effective means of communication and serves only to confuse or mislead'. The disease may manifest itself in single words or phrases, or in passages of any length.

One must emphasise that diseased English is not the same as misused English. The BBC sub-editor who, in the course of writing a news-item, said 'She was taken to Poole General Hospital, where she was said to be satisfactory', was merely careless or semi-literate, since it was the lady's condition, one hopes, not the lady herself, which was satisfactory. Nobody, however, was confused or misled by the mistake. Similarly, the use of 'the promoter is wide-open' instead of 'the choice of promoter is wide-open' may be inelegant and unfortunate, but it is not diseased, at least in the present Dictionary's use of the term. 'Superb gourmet dining', on the other hand, in an advertisement for an expensive and fashionable restaurant, serving notably undistinguished food, is diseased. Such a description is aimed at causing the customer to believe that he is getting food close to the world's best, when in fact what he is being sold is an assembly of expensive edible clichés. The fact that most of the restaurant's customers are willing partners in the swindle is an indication of how deep-rooted the disease has become.

The present Dictionary is the result of an extensive and not always pleasurable search through books, newspapers and periodicals published in the English-speaking world during the past ten years. It is necessarily illustrative, rather than comprehensive. 'This,' it says in effect, 'is what feckless, ignorant and socially irresponsible people are doing to our language.' Every page and every item is meant to be a call to arms. It is not a culturally-neutral volume and some readers will undoubtedly find it prejudiced.

But the situation has become too serious for the suppression or toning-down of one's convictions. If any improvement is to be possible, one has to hit out. As George Orwell so wisely said thirty 


\section{Introduction}

years ago, 'one ought to recognise that the present political chaos is connected with the decay of language, and that one can probably bring about some improvement by starting at the verbal end'.* The process of decay, Orwell pointed out, feeds on itself. 'A man may take to drink because he feels himself to be a failure, and then fails all the more completely because he drinks. It is rather the same thing that is happening to the English language. It becomes ugly and inaccurate because our thoughts are foolish, but the slovenliness of our language makes it easier for us to have foolish thoughts.' Modern writing at its worst, he went on to say, 'does not consist in picking out words for the sake of their meaning and inventing images in order to make the meaning clearer. It consists in gumming together long strips of words which have already been set in order by someone else, and making the results presentable by sheer humbug.'

The cumulative effect, the gumming together, is what matters most, nonsensical and twisted in themselves as the individual words and phrases may be. A dictionary can only indicate the bricks; the walls from which they are made are material for an anthology. $A n$ Anthology of Diseased English would be a natural companion to the present volume, and one hopes that its appearance will not be long delayed. $\dagger$ Meanwhile, one can do no more than indicate the kind of extracts it will contain. Publishers' advertising, for instance, would be well represented:-

'The world's greatest writers of fiction have all created stories that are immortal masterpieces. Works of such imaginative power that they have the force of actual experience. Works of such wit and wisdom that they illuminate the nature and meaning of life. Works of such rich variety, that they penetrate every aspect of human existence and have become part of the literary heritage of all mankind.

* 'Politics and the English Language'. Originally published in 1946 and quoted here from The Collected Essays, Journalism and Letters of George Orwell, ed. Sonia Orwell and Ian Angus, Vol. IV, 1968.

† For some time the Washington Star has given its readers an opportunity to build up at least part of such an anthology with very little effort. It runs a regular feature called 'Gobbledygook', which is devoted to examples of officialese. \$ 10 is paid for each entry printed. A typical item (19.10.76) was: 'When previously processed prior pay period adjustments were made for multiple pay periods, the overtime hours and/or premium pay was computed in the same manner as each of the other pay periods, using the overtime hours and/or premium pay from the period with the highest amount of overtime hours or premium pay (except for the Christmas period) to provide employees with the maximum possible benefit.' This was part of a notice to U.S. Postal employees. 
Now, for the first time, these masterpieces of fiction are to be published in a truly luxurious collection-forming a library of great literature unlike any other ever published before. A private library devoted exclusively to the greatest stories of the world's greatest writers of fiction.

Each of the one hundred guest authors represented in this collection is a giant of world literature. A towering figure who brought the art of fiction to a peak of perfection. And each volume in this unique series will contain the finest stories of one of these great authors. In one hundred sumptuous volumes, each bound in genuine leather-this magnificent edition will include ...*

The dividing line between 'diseased' and 'exaggerated' is thin and elusive, but the exaggerations so liberally scattered over the passage just quoted are the symptoms of disease and are certainly capable of bemusing and confusing the more innocent reader and, with luck, hypnotising him into buying books which he may or may not eventually enjoy.

The art writers would certainly be present in our anthology in force with such flashes of insight as:-

'It seems wholly illogical that although most of Barbara Hepworth's drawings are representational, most of her sculptural oeuvre is organic. It would therefore be impossible to simplify down to the inner arresting movement if confined to chiselling a synthesis of human figuration. When art has to be fundamental no distracting detail is possible. There must only be a totality concentrated in Oneness. $\dagger$

and

'What attests to Boogaert's increased self-assurance as an artist is that he realises that he does not need a blatantly obvious pattern or configuration to get across the idea of an imposed mental structure; it is inherent in the fact that he has broken a continuous unmarked temporality into discrete units. That the differences between the individual frames of a given contact sheet frequently lie beneath the

* Supplement to the Boston Sunday Globe, advertising the Franklin Library, 3rd October I976.

† Connoisseur, Vol. 163, Sept./Dec. 1966. A high proportion of the art critics writing in English are of Continental, especially German, origin. This is certainly one reason for their strange jargon. They use it primarily as a kind of lingua franca, for communication with other art critics, not with the public. 


\section{Introduction}

threshold of perception does not disturb him. He is after all only reporting the results of applying a particular schema upon a natural phenomenon.'*

The psychologists and psychiatrists would have a generous contribution to make:-

'Other group modalities often used with children and play, behavior modification, and the verbal approach ... Play materials are selected to evoke group members' expression and resolution of personal conflicts. Therapeutic ingredients are the therapist-child relationship and therapist clarificationinterpretation of feelings expressed through the child's play. Member-to-member interaction is seen as less important in play than in activity-group treatment. In behavior techniques, the armentarium of behavioral techniques is applied. Treatment goals are limited to the modification of specific behaviour patterns. The verbal group therapies include client-centred counseling and insight-oriented psychotherapy. Definitive features of these modalities and discussion of the patients' problems and mobilisation of member-to-member and member-to-therapist interaction to improve psycho-behavioral functioning.' $\uparrow$

The sociologists would be queueing up for inclusion, with such passages as:-

'A factor of considerable importance in naturalistic socialization contexts is the timing of punishment. In home situations, punishment is often delayed beyond the completion of the deviant behavior. Does the timing of the administration of a punishment affect its effectiveness as a means of inhibiting undesirable behavior? Mowrer (I960) has provided a theoretical framework for predicting the effects of the timing of punishment. According to Mowrer, each component of a response sequence provides sensory feedback in the form of response-produced kinesthetic and proprioceptive cues. Punishment may be administered at any point during the sequence of responses and result in a relatively direct association of a fear-motivated avoidance response with the response-produced cues occurring at the temporal locus of punishment. If the punishment is administered at the initiation of

* Arts Canada July/August 1976. Article on Pierre Boogaerts by Walter Klepac.

$\dagger$ Archives of General Psychiatry Chicago, March 1976.

xxii 
the deviant response sequence, the maximal degree of fear is attached to the cues produced by the instrumental acts involved in initiating the sequence. In this case, subsequent initiation of the sequence will arouse anxiety that activates incompatible avoidance responses, which are reinforced by anxiety reduction if they are sufficiently strong to forestall the deviant behavior.'*

And so on through the management writers, the educationists, the politicians, the wine and food writers, the lawyers, the theologians, the ballet, music and literary critics, and the rest of our contemporary wordmongers for whom simplicity and directness are apparently so difficult and unnatural. One uses the term 'wordmonger' deliberately, because, nagging away in the back of one's mind there is always the suspicion that these people may really have nothing to say, and that mere words are all they have to offer, that the medium is in fact the message. It is a matter of experience and observation that someone with a genuine piece of information can usually manage to communicate it in a reasonably straightforward and intelligible way. The verbal nonsense tends to come from people with nothing to say, but with a powerful vested interest in saying it impressively. Sorting out the sheep from the goats is a skilled business, which demands great ruthlessness and objectivity and is certain to make enemies, many of them in high places.

The reader may feel that the present work deals somewhat harshly at times with certain categories of writer, more especially perhaps those who earn their living, or part of their living, from giving their opinions on music, ballet, painting, food and wine. This is certainly from no spirit of malevolence. On the contrary, it is fully recognised that the task of expressing sensual pleasures in words is extraordinarily difficult and that it is right and natural to strain language to the utmost in an effort to communicate what one has seen, heard and tasted. Such striving and wrestling with words is the poet's everyday problem and duty. There is nothing new or unreasonable about it. What has to be remembered, however, is that the critic, unlike the poet, is paid to communicate. If the wine critic of The Times or the ballet critic of The Guardian writes and publishes something that makes no sense to the majority of the people who read these articles, then the critics must be considered to have failed. A critic is a communicator, and if his attempts to communicate meet with little success, he should either try another approach or look for another job.

* Ronald A. Hoppe et al. Early Experiences and the Process of Socialisation New York, I 970. 


\section{Introduction}

An editor or a publisher can be put in a very difficult position by such specialists. On the one hand he must trust them and, up to a point, give them their head, but on the other he has a responsibility to his readers to restrain the most extreme excesses. He must have the power to say, 'This makes no sense'; 'Do something about it.' This, however, can be dangerous, because today's apparent nonsense can be tomorrow's crystal-clear good sense. The first-class critic, like the first-class artist, is always to some extent ahead of his times. The editor of an internationally famous art magazine confessed to the present author that quite frequently he found himsef unable to understand the articles written by one particular expert on contemporary art. 'But,' he went on to say, 'I think he's an honest man, so I print what he sends me'. It is a point of view which is bound to command one's respect, however baffling the articles in question may seem.

It will be evident from the following pages that a special effort has been made to track down and struggle to interpret the often very strange language employed by an interesting and influential body of experts, the wine-writers. This is partly because the problem is important in itself - a great deal is written and read about wine in the course of a year-and partly because wine-writing is a microcosm of at least part of our culture. By analysing it and trying to understand what is in the writer's mind, one is brought on close terms with what is admirable and absurd, rewarding and futile, in our society. Discussion about wine with wine-professionals is usually as fruitless and infuriating as conversations between a devoutly religious person and someone who has never experienced the power of religion. At some point the expert is likely to have to say, 'I can't put it any more plainly. There are no words to express what I feel. You'll simply have to believe me and take it all on trust.'

But, as we have said before, there are great dangers in accepting this point of view. It makes life too easy for the phonies, for those who see advantages in disguising themselves as the real people. If one tries as hard as one can to understand what another person is saying, and no sense comes out of it, it is always safer to assume that one is in contact with a fraud, rather than a genius. One may be wrong at times, but less often than by assuming the opposite. Any good communicator understands very well when something is likely to be difficult to explain or express, and at such times he will use all his skill to meet his listeners or readers half-way. The poor communicator either fails to understand the problem or dismisses the doubters and questioners as morons. 


\section{Introduction}

Wine-critics do, in all fairness, occasionally try to reveal what lies behind their strange language. They rarely succeed. Their explanations are often as perplexing as the words that occasioned them. The wine-critic of The Times, for instance, a lady highly and rightly respected in her profession, recently made a big effort to instruct the readers of a popular women's magazine* in the significance of winewords. The term 'finesse', she said, 'has been neatly summed up as the sort of thing that makes you order the second bottle so as to find out more about what the wine really is like'. It is hardly a definition, and she has little better luck with two other favourites, 'breed' and 'elegance'. These, one is told, 'are terms that it's easy to interpret as regards wine because they mean virtually the same sort of thing as when you are describing people-a wine can obviously have 'breed' (sic), even if you don't really like it, and it may be 'elegant' on some occasions when you couldn't have expected it to be more than adequately turned out.' We are, alas, not a great deal further forward.

It should be emphasised with all possible vigour that the Dictionary has absolutely no prejudice against innovation and change in English or any other language. Nor can there be any objection to necessary technical terms. It is essential that every generation should make its own contribution to the strength and flexibility of the mothertongue. Ideas and circumstances are always in movement and language, if it is to remain in a state of health, has to adjust itself to new patterns of living. It cannot remain static. What the following pages try to dissect and expose is bogus innovation, language which has a shiny and saleable veneer and nothing but rotten wood underneath. Four classes of people are particularly guilty of this crime against their fellow-men:-

I. The padders and puffers, those who have a given amount of space to fill and whose living depends on filling it at all costs.

2. The inflators, those who have something very simple or banal to say, but who feel driven, for reasons of prestige, to make it sound much grander than it really is.

3. The whitewashers, those who are hired to put a pretty face on ugly things.

4. The confidence tricksters, those who have nothing to say at all, but whose livelihood and power demand that the public shall be hypnotised into thinking that they are giants and geniuses. 


\section{Introduction}

Diseased English is spread by these people. They are carriers of infection and need to be identified, isolated and, wherever possible, cured, before their kind of English becomes accepted as normal.

Correspondence on these subjects is often far from easy. A firm, a Government department or an individual is likely to react badly to the slightest suggestion that it, he or she has been responsible for prose which is anything less than crystal clear and impeccably stylish. Threats of prosecution are not uncommon. During 1976, for instance, one of the foremost management recruitment companies in Britain had a large newspaper advertisement, which included two seriously ungrammatical items, the first, 'our client are continuing', and the second 'the companies service'. The firm was asked if what actually appeared in print, 'is an exact reproduction of the copy you sent in, since newspapers do occasionally make a mistake', and it was suggested that advertisements phrased in this way might do the reputation of the company no good. The reply was 'that the advertisement in question appeared in the form it did as a result of factors beyond the control of this company', and that the company 'would reserve the right to take such legal action as might be deemed appropriate if your comments in a published work were in any way similar to those expressed in your letter'. Words, however, do not select themselves. If the blunders referred to did not come from the recruitment company, either the client or the newspaper must have been responsible. Illiteracy was clearly in the air and contaminating this particular job to such an extent that fully educated candidates might well have decided not to apply. No threats of legal action could blow that fact away.

The major villains in the language play change somewhat from decade to decade. In the r930s the principal culprits, at least in English, were probably advertising people, with the lawyers and the civil servants hard on their heels. During the I940s, the politicians, the bureaucrats and the armed forces overtook and passed the front runners of the previous decade, the war years having added greatly to the power and influence of all three. The Fifties and Sixties, however, gave immensely increased opportunities to social scientists and to the Booming Economy and Good Life people, who developed their own kinds of nonsense language at an alarming speed and almost without the linguistic doctors realising that the disease was changing its symptoms. The entries in this Dictionary, covering the years $1966-76$, consequently have a different flavour from what one would have found if the pond to be dragged had been, say, 1936-46. 1976-86 
will almost certainly produce its own peculiar crop. This is a dictionary which, in the public interest, needs to be re-made every ten years.

To some extent, the proportion of entries from different fields of human activity reflects the number of words which each of these has hurled at the ear and the eye during the decade. The sociologists, the psychologists, the management experts, the new-style bureaucrats, the industrialists with the bit between their teeth, the people with holidays, hotels and restaurants to sell, the entertainment impresarios-all these have had a prodigious amount to say for themselves during a period in which they, at least, have never had it so good. Forecasts are always dangerous, but there is no harm in chancing the opinion that the top producers of linguistic rubbish between 1976 and 1986 will be the trade unions, religious bodies, the medical profession and extremist political groups-all people who flourish when times are bad.

Some things, none the less, are timeless, and in reading the entries which follow, one should never lose sight of the fact that communication is quite as much a matter of the emotions as of the intellect. One can write or speak absolute rubbish, but, if it is the right kind of rubbish, it can bring one an abundance of friends and allies among people who habitually use the same variety of nonsense language. There are no stronger links than those between sufferers from the same illness, even when that illness is madness. To the irreverent layman, 'each component of a response-sequence provides sensory feedback in the form of response-produced kinesthetic and proproceptive cues' sounds like pompous piffle, which indeed it is, but to a fellow psychologist or sociologist it indicates a friend, someone with his head and heart in the right place, someone worth knowing. For the initiates it is rank-closing, masonic language, with no power to stimulate those who live outside the group. The magical quality of linguistic rubbish can be underestimated, but one is still entitled to say that such language rots both society and the individual, and this Dictionary takes pride in making its point of view clear, no matter how much it may annoy and unsettle those who believe that group loyalty is the supreme virtue.

There is, however, one encouraging feature to be noticed, and it would be a pity not to end this Introduction on a note of optimism. The wretchedly corrupt English of the groups which happen to enjoy great power at any particular time always, in a democratic society, produces a reaction against it. This sometimes comes in the form of 


\section{Introduction}

ridicule, sometimes of direct attack. The advertisers, the doctors, the lawyers and the sociologists, for example, have all been pilloried for the follies and crimes of their language, and the world is a sweeter place as a result. A comparison between some of the professional journals now and twenty or thirty years ago will reveal a very great improvement. It would be rather tedious to list here the professions and publications which have done themselves great benefit in this way, ${ }^{*}$ but an illustration can do no harm. The British Medical Journal is quite remarkably free from jargon these days. This seemed to call for a letter of congratulation to the Editor, whose answer deserves the widest possible publicity.

'We do have a strong feeling about the English language,' he wrote, 'Our copy is fairly heavily subedited-particularly in the teaching sections (that is, leading articles and Medical Practice) and we also routinely change wrong phrases (mitigate against) wherever they occur. I am particularly interested in trying to eliminate gobbledygook. I think many articles remain unread because subliminally the effect of bad English prevents the reader from glancing through more than the first paragraph, and I have run a number of courses in medical writing in Britain, Europe and the Middle East to try and get this across.'

It can be done.

* The task has been carried out with some thoroughness in the author's forthcoming book, The Jargon of the Professions, due for publication by Macmillan in 1977. 